\title{
Comparative Assessment of Indoor Air of a Tertiary Hospital and a Public Secondary School in Ilorin, Kwara State, Nigeria
}

\author{
0. C. Adekunle1, B. K. Abdulkareem ${ }^{1}$, 0. A. Adewumi ${ }^{1}$, T. O. Sanusi² \\ ${ }^{1}$ Department of Medical Microbiology and Parasitology, Ladoke Akintola University of Technology, Osogbo, Nigeria \\ ${ }^{2}$ Department of Community Medicine, Ladoke Akintola University of Technology, Osogbo, Nigeria \\ Email: ^toyintoro@yahoo.com
}

How to cite this paper: Adekunle, O.C., Abdulkareem, B.K., Adewumi, O.A. and Sanusi, T.O. (2018) Comparative Assessment of Indoor Air of a Tertiary Hospital and a Public Secondary School in Ilorin, Kwara State, Nigeria. Advances in Microbiology, 8, 931-937.

https://doi.org/10.4236/aim.2018.812062

Received: June 27, 2018

Accepted: December 11, 2018

Published: December 14, 2018

Copyright $\odot 2018$ by authors and Scientific Research Publishing Inc. This work is licensed under the Creative Commons Attribution International License (CC BY 4.0)

http://creativecommons.org/licenses/by/4.0/

\begin{abstract}
Air bone transmission is one of the routes of spreading diseases responsible for a number of nosocomial infections [1]. Airborne microbial particles have negative effects especially on the health of immunocompromised people [2]. The infections are caused by aerosols which are small, viable and may remain suspend in the air stream over long period of time. This study was aimed at investigating and comparing the quality of indoor air of a tertiary hospital and a secondary school in Ilorin, Kwara state, Nigeria. Air samples were collected in the hospital and school using settle plate techniques. Bacteria isolated from different wards in the hospital were Staphylococcus aureus, Coagulase negative Staphylococcus, Bacillus spp., Klebsiella spp., Micrococcus spp., Escherichia coli, Pseudomonas spp., Acinebacter spp. The female surgical ward (FSW) had the highest degree of contamination of bacterial and fungal air borne while the bacterial isolates gotten from the school were heavy growth of Coagulase negative Staphylococcus and Bacillus spp., and few growths of Klebsiella spp. and Acinebacter spp. with highest bacterial count in J.S.S.2B class. For fungal growth Aspergillus spp. and Mucor spp. produced numerous growths in all the classes and in the hospital while Penicillium spp. gave scanty growth. The lowest bacterial count observed both in school and in hospital was still high when compared with British bacteriological standard.
\end{abstract}

\section{Keywords}

Indoor Air, Nosocomial Infections, Microbial Particles, Penicillium

\section{Introduction}

Indoor air quality refers to the air within and around buildings and structures. It 
can be made unsafe for human use by some compounds, such as carbon monoxide, volatile organic compounds, particulate matter and microbial contaminants, such as moulds, bacteria and viruses [3]. Dust is a good vehicle of air borne contamination and emanates from human activities, such as sweeping, movement, waving of handkerchief and bed making [4].

Patients with community acquired infection are frequently admitted to the hospital and the diseases may spread nosocomially by either direct contact, contact with contaminated food, water, medication or medical devices (fomities) or by air borne transmission [5]. Many bacteria are spread through air which includes Mycobacterium tuberculosis, Bacillus anthracis, Bordetella pertusis which cause pulmonary tuberculosis, pulmonary anthracis and whooping cough respectively [6]. These diseases may be fatal if not treated early. Fungi, such as Apergillus niger, Candida albican and Penicillium are capable of causing hospital acquired infections.

There is a need to assess indoor air quality especially in institutions, such as hospital settings, nursing homes, prisons, schools, dispensaries and banks which are characterized by influx of people, because it has been reported that contaminated air can cause both mild and severely irritating health conditions [7].

It has been reported that air borne bacteria in the hospital environment have been a major source of post operative infection and serious problem in the intensive care unit [8].

This study was aimed at investigating the quality of indoor air of a tertiary hospital and a secondary school in Ilorin, Kwara State, Nigeria.

\section{Materials and Methods}

This work was carried out at University of Ilorin teaching hospital and Ilorin Comprehensive High School. The hospital study sites included Neonatal Intensive Care Unit (NICU), Labour Ward (LW) Operating Theatre (OT), Male Medical Ward (MMW), Female Medical ward (FMW), Male Surgical Ward (MSW), Female surgical ward (FSW), Children Ward (CW) and Accident and Emergency Unit(A/E). Four sampling points in each ward and in a classroom and in each point blood agar, chocolate agar, macconkey agar, and sabouraud agar were used for sample collection.

Air samples were collected in the hospitals thrice a day namely in the morning before cleaning (6:00 - 7:00 am), morning shortly after cleaning (7:00 - 8:00 am) and lastly in the evening 4:00-6:00 pm.

The Ilorin Comprehensive High School sites included 10 classrooms which were J.S.S 2B, J.S.S.3A, J.S.S.3B, J.S.S 3C, S.S 1B, S.S.1D, J.S.S 1B, S.S.3D, S.S. 2C. Settle plate techniques were employed using petri-dishes containing different culture media was used (Crook, 1995). Culture plates contain blood agar, chocolate agar and Macconkey agar for bacterial isolates while Sabouraud dextrose agar was used for fungal isolates. The sampling was done in the noon. The culture plates were distributed at different locations in the classrooms and exposed 
face upwards and allowed to stay for an hour.

The bacterial culture plates were incubated at $37^{\circ} \mathrm{C}$ for $24-48$ hours while the fungal culture plates were incubated at room temperature $\left(20^{\circ} \mathrm{C}-28^{\circ} \mathrm{C}\right)$ for $3-4$ days. After incubation the total number of colony forming unit (CFU) for the bacterial and fungal air flora were at calculated using the polish standard (Friberg et al., 1999).

$$
\mathrm{CFU} / \mathrm{M} 3=a \times 1000 / p x+0.2
$$

where $a=$ the number of colonies on the petri plate; $p=$ the surface measurement of the plate used $(90 \mathrm{~mm}) ; \mathrm{T}=$ the time of exposure of the petri plate.

Identification of micro-organisms bacterial colonies were characterized by cultural, morphological, biochemical, and microscopic examination. Obtained results were compared with specifications in Bergey's Manual of Systematic Bacteriology (Garrity et al., 2005).

The fungal colonies were identified and enumerated, examined macroscopically and microscopically. They were characterized based on their morphological features such as distinctive possession of spore and hyphae (Betty et al., 2007).

\section{Results}

The highest number of bacteria was observed in female surgical ward and the lowest in the operation theatre as shown in Table 1. The classroom J.S.S 2B had the highest number of bacteria while S.S.S 2A had the lowest number of bacteria isolated as observed in Table 2. Also, female surgical ward had highest number of fungi and lowest number of fungi recorded was in the operation theatre in Table 3. The same hospital venue which had the highest number of bacteria also had the highest number of fungi and the same venue which had the lowest number of bacteria also had the lowest number of fungi. On the contrary, highest number of fungi was cultured from J.S.S 3A classroom in Table 4. Bacteria

Table 1. Enumeration of hospital air bacteria $\left(\mathrm{CFU} / \mathrm{m}^{3}\right)$ in different wards.

\begin{tabular}{cccc}
\hline Study Area & Morning before cleaning & Morning after cleaning & Evening \\
\hline FSW & 354 & 94 & 289 \\
MSW & 106 & 265 & 220 \\
FMW & 237 & 41 & 96 \\
MMW & 35 & 30 & 57 \\
LW & 81 & 26 & 96 \\
A \& E & 113 & 70 & 11 \\
OT & 20 & 4 & 72 \\
NICU & 87 & 9 & 43 \\
CW & 57 & 50 & 96 \\
\hline
\end{tabular}

Key: FSW-Female surgical ward; MSW—Male Surgical Ward; FMW-Female Medical ward; MMN-Male Medical ward; LW-Labour Ward; A \& E-Accident and Emergency Unit; NICU-Neonatal Intensive Care Unit; CW-Children Ward; OT-Operation Theatre. 
Table 2. Enumeration of classroom air bacteria in Ilorin Comprehensive High School.

\begin{tabular}{cc}
\hline Classrooms Sampled & Total bacterial count $\left(\mathrm{CFU} / \mathrm{m}^{3}\right)$ \\
\hline J.S.S 2B & 183 \\
J.S.S.3A & 153 \\
J.S.S.3B & 158 \\
J.S.S.3C & 155 \\
S.S.S.1B & 169 \\
S.S.S 1D & 173 \\
S.S.S.2A & 149 \\
J.S.S.1B & 169 \\
S.S.S.3D & 171 \\
S.S.S.2C & 161 \\
\hline
\end{tabular}

Table 3. Enumeration of hospital air fungi $\left(\mathrm{CFU} / \mathrm{m}^{3}\right)$ in different wards.

\begin{tabular}{cccc}
\hline Study Area & $\begin{array}{c}\text { Morning Before cleaning Morning After cleaning } \\
(6: 00-7: 00 \mathrm{am})\end{array}$ & $\begin{array}{c}\text { Evening } \\
(7: 00-8: 00 \mathrm{am})\end{array}$ & $\begin{array}{c}(4: 00-5: 00 \mathrm{pm}) \\
\text { FSW }\end{array}$ 117 $^{\text {MSW }}$ \\
59 & 22 & 43 \\
FMW & 63 & 43 & 35 \\
MMN & 44 & 22 & 33 \\
LW & 46 & 56 & 15 \\
A \& E & 28 & 20 & 30 \\
OT & 31 & 7 & 20 \\
NICU & 81 & 30 & 24 \\
UN & 59 & 85 & 17 \\
\hline
\end{tabular}

Key: FSW—Female surgical ward; MSW—Male Surgical Ward; FMW—Female Medical ward; MMN-Male Medical ward; LW-Labour Ward; A \& E-Accident and Emergency Unit; NICU-Neonatal Intensive Care Unit; CW-Children Ward.

Table 4. Enumeration of classroom air fungi in the Ilorin Comprehensive High School.

\begin{tabular}{cc}
\hline Classrooms & Total fungal count $\left(\mathrm{CFU} / \mathrm{m}^{3}\right)$ \\
\hline J.S.S $2 \mathrm{~B}$ & 30 \\
J.S.S 3A & 37 \\
J.S.S 3B & 27 \\
J.S.S 3C & 31 \\
S.S.S 1B & 35 \\
S.S.S 1D & 31 \\
S.S.S 2A & 32 \\
J.S.S 1B & 28 \\
S.S.S 3D & 33 \\
S.S.S 2C & 22 \\
\hline
\end{tabular}


isolated from different wards in the hospital were Staphylococcus aureus, Coagulase negative Staphylococcus, Bacillus spp., Klebsiella spp., Micrococcus spp., Escherichia coli, Pseudomonas spp., Acinebacter spp., Bacillus spp., Acinebacter spp. and Klebsiella. Acinebacter spp. and Klebsiella produced scanty growth while the growth of other bacteria was numerous. The bacterial isolates gotten from the school were heavy growth of Coagulase negative Staphylococcus and Bacillus spp., and few growths of Klebsiella spp. and Acinebacter spp. as shown in Table 5. Table 6 shows that the fungi namely Aspergillus spp. and Mucor spp. produced numerous growths in all the classes while Penicillium spp. gave scanty growth.

\section{Discussion}

Build up of infection aerosols exacerbates with care challenges and developing country as the role of airborne microorganisms in hospital acquired infections (HAIS) has been recognized [2]. Airborne microorganisms contaminated are usually introduced into the air through production of aerosol droplets by human via coughing, sneezing and talking.

In door environments, the main source from microbes is usually the outdoor air [9].

The results showed that the female surgical ward (FSW) had the highest degree of contamination of bacterial and fungal air borne followed by male surgical wards. This was also observed by Awosika et al. [4]. This high viable count in these wards might be associated with improper ventilation, high movement of individuals and poor level of awareness among the staff and routines wound dressing which might result in shedding of bacteria, especially when those patients have surgical site infections. The total viable microbial count in female surgical ward and male surgical ward showed high contamination level and exceeded available local guideline according to Ekhaise et al. [10] [11] [12].

Table 5. Frequency of occurrence of bacterial isolates from classrooms sampled.

\begin{tabular}{cccccccccccc}
\hline Isolates & JSS2B & JSS3A & JSS3B & JSS3C & SS1B & SS1D & SS2A & JSS1B & SS3D & SS2C \\
\hline Baccilus spp & +++ & ++ & +++ & +++ & ++ & ++ & ++ & +++ & +++ & ++ \\
CoNS & +++ & ++ & ++ & ++ & ++ & ++ & ++ & ++ & +++ & ++ \\
Klebsiella & + & - & - & + & - & + & - & - & + & + \\
Acinetobacter & + & + & + & - & + & - & + & - & + & + \\
\hline
\end{tabular}

Key: CoNS—Coagulase negative Staphylococcus; +++: Numerous; ++: Moderate; +: Few; -: Negative.

Table 6. Frequency of occurrence of fungi isolates from classrooms sampled.

\begin{tabular}{ccccccccccc}
\hline Isolates & JSS2B & JSS3A & JSS3B & JSS3C & SS1B & SS1D & SS2A & JSS1B & SS3D & SS2C \\
\hline Aspergillus & +++ & +++ & +++ & ++ & ++ & +++ & +++ & +++ & +++ & ++ \\
Mucor & ++ & - & ++ & ++ & ++ & ++ & - & ++ & +++ & +++ \\
Penicillium & + & + & + & + & - & + & - & - & + & - \\
\hline
\end{tabular}

Key: +++: Numerous; ++: Moderate; +: Few; -: Negative. 
The result from the school showed that the highest bacterial count was obtained in J.S.S.2B class. This might be as a result of the class population. It is the classroom with the highest number of pupils. It could be as a result of the pupils' activities: they were very playful. The operating theatre (OT) recorded the least microbial concentration. The total viable bacterial count in the theatre ranges from 2 to $20 \mathrm{cfu} / \mathrm{m}^{3}$ while fungal count ranges 3 to $7 \mathrm{cfu} / \mathrm{m}^{3}$. Friberg and his colleagues suggested that the current British bacteriological standard for ultraclean operating room is $<10 \mathrm{cfu} / \mathrm{m}^{3}$, a corresponding standard for surface contamination rate of $<10 \mathrm{cfu} / \mathrm{m}^{3}$, a corresponding standard for surface contamination rate of $<350 \mathrm{cfu} / \mathrm{m}^{3} / \mathrm{h}$ measured by means of settle plates. This result indicates that the total viable bacterial and fungal count in operating theatre (at rest) is high when compared with standard acceptance level. The lowest bacterial count was observed in S.S. 2A class which is still high when compared with British bacteriological standard. This indicates that the students' classrooms are not sterile and the students can be infected with the pathogenic microorganisms present in the classrooms. These may pose health hazards to the students and teachers, especially the immunocompromised. Thus, there is a need for awareness for infection control. The teachers and the students need to be sensitized about the spread of infection through the air.

This hospital could be the source of infection to patients, visitors as well as the hospital staff. The wards can act as area where there are various influencing factors that can contribute to patients acquiring infection during the hospital visit [13].

\section{Conflicts of Interest}

The authors declare no conflicts of interest regarding the publication of this paper.

\section{References}

[1] Claudette, R.P., Krebs, V.L.J., Auler, M.E., Ruiz, L.S., Matsumoto, F.F., Elza, H.S., Dwiz, E.M.A. and Vaz, F.A.C. (2006) Nosocomial Infection in Newborns by Pichiaanomala in Brazilian Intensive Care Unit. Medical Mycology, 44, 479-484. https://doi.org/10.1080/13693780600561809

[2] Bhatia. (2011) Impact of Bio-Aerosols Indoor Air Quality-A Growing Concern. Advances in Bioresearch, 2, 120-123.

[3] Omoigberale, M.O., Amen Gailue, O.O. and Iyanu, M.I. (2013) Microbiological Assessment of Hospital Indoor Air Quality in Ekpoma, Edo State. Global Research. Journal of Microbiology, 4, 1-5.

[4] Awosika, S.A., Olajunbu, F.A. and Amusa, N.A. (2012) Microbiological Assessment of Indoor Air of a Teaching Hospital in Nigeria. Asian Pacific Journal of Tropical Biomedicine, 16, 465-468.

[5] Yu, B.F., Hu, Z.B., Liu, M., Yang, H.L., Kong, Q.X. and Liu, Y.H. (2009) Review of Research on Air-Conditioning Systems and Indoor Air Quality Control for Human Health. International Journal of Refrigeration, 32, 3-20. 
[6] Sudharsan, S., Srikanth, P., Sheela, M. and Stienberg, R. (2008) Study of Indoor Air Quality in Hospital in South Chennai, India. Indoor Built Environment, 17, 435-441.

[7] Tambekar, D.H., Gulhane, P.B. and Bhakare, D.D. (2007) Studies on Environmental Monitoring of Microbial Air Flora in Hospitals. Journal of Medical Sciences, 7, 67-72.

[8] Newman, M.J. (2002) Neonatal Intensive Care Unit Reservoir of Nosocomial Pathogens. West African Journal of Medicine, 21, 310-312.

[9] Nevalainen, A.K. and Morawaska, L. (2009) Biological Agents in Indoor Environment. Assessment of Health Risks. Work Conducted by a WHO Expert Group between 2000-2003. WHO, QUT.

[10] Ekhaise, F.O., Ighosewe, O.U. and Ajaakpori, O.D. (2008) Hospital Indoor Airborne Micro-Flora in Private and Government Owned Hospitals in Benin City, Nigeria. World Journal of Medical Sciences, 3, 34-38.

[11] Ekhaise, F.O., Isitor, E.E., Idehen, O. and Emoghene, A.O. (2010) Airborne Microflora in the Atmosphere of a Hospital Environment of University of Benin Teaching Hospital (UBTH), Benin City, Nigeria. World Journal of Agricultural Sciences, 6, 166-170.

[12] Ekhaise, F.O. and Ogboghodo, B. (2011) Microbiological Indoor and Outdoor Air Quality of Two Major Hospitals in Benin City, Nigeria. Sierra Leone Journal of Biomedical Research, 3, 169-174.

[13] Bhattacharyya, S., Rana, R.K., Sarfraz, A., Sengupa, A. and Kumar, D. (2015) Study of Aerial Microbial Flora of Different Departments of a Tertiary Care Hospital in Eastern India. International Research Journal of Medical Sciences, 3, 11-12. 